\title{
Ethnic Entrepreneurs and Political Mobilization: Exploring a Case of Tharu-Pahadi Conflict
}

\author{
Ishwari Bhattarai
}

\begin{abstract}
Nepalese society today is witnessing an unprecedented sharpening of ethnic boundaries. In the last couple of decades or so, there have been growing instances of inter-ethnic conflict and clashes. The clash among the Tharus and Pahadi (Bahun-Chhetri) communities that took place in the month of May, 2012 in the Nawalparasi district is one such example. Borrowing the conceptual idea from Fredreick Barth (1995) who critically engages with the question of culture, ethnicity, and contemporary nature of ethnic mobilization, this paper seeks to explore how such conflicts are an epiphenomena of tactical moves carried out what he calls as 'middle echelon politicians'. Through the qualitative data collected with the help of open-ended interviews and couple of other illustrations, this paper argues that, the contemporary character of ethnic mobilizations in some way or the other, are manipulated by ethnic entrepreneurs who politicize cultural differences, ethnic sentiments, and collective backwardness which often result in violent confrontations. Despite the Tharus being diverse and sharply divided in terms of political allegiance and electoral behavior, the leaders or activists use politics of cultural difference, and attempt to mitigate internal differences, to present a consolidated picture of ethnic unity. Through such actions ethnic leaders or activists selectively mobilize ethnic sentiments and symbols in order to motivate members of an ethnic group and also assume leadership position at both local and national levels.
\end{abstract}

Keywords: ethnicity, ethnic entrepreneurs, political mobilization 


\section{2| Ishwari Bhattarai}

\section{The Context}

Ethnic politics has acquired centre stage in Nepal today. In the last decade, politicization of all social groups has gained momentum. All castes and communities have begun to make radical demands aftermath of the success of 2006 democracy movement, popularly called jana andolan II, the 2nd people's movement, assuming that a similar kind of people's movement, jana andolan I, took place in the year 1990. The nature and the character of the second people's movement was qualitatively different from the first one. Although the level of political consciousness among people has increased since 1990, the intensity of ethnic group mobilization has become much higher after 2006. All hitherto politically and culturally marginalized ethnic groups have become more vocal and have begun to articulate their voice for greater representation in the socio-political system and also demanded for restructuring the state. The successive governments formed after 2006 brought a series of changes in the conception of Nepalese polity ${ }^{1}$ and the former Hindu Kingdom became a secular polity, shifting the erstwhile discourse of hill-centric monocultural national narrative to the need for a multicultural recognition and accommodation of cultural differences.

Seen in this context, the ethnic politics and mobilization has yielded several optimistic outcomes, and it has generated a great deal of enthusiasm among the ethnic leaders and caste or community members. It has developed a sense of dignity and confidence among various ethnic communities including the dalits in the recent past.

1. Some of the selective key events were, reinstating of the parliament in April 2006 that was dissolved by the King in 2002, new interim constitution was introduced, declaring Nepal a secular state, the interim constitution was amended introducing the provision of federal restructuring after the Madhesh movement in 2007, held constituent assembly elections in 2008 to write a new constitution, 240 years old Nepalese monarchy was abolished by the 2/3rd majority of Constituent Assembly members on May 28, 2008. Being unable to promulgate the constitution in the stipulated time of two years, and after repeated extensions, the Constituent Assembly tenure was expired on 28th may 2012. The second Constituent Assembly elections were held in the month of November 2013 and with much deliberations finally, a new constitution was promulgated on 20th September 2015. 


\section{3| Ishwari Bhattarai}

Furthermore, it has changed the course of intra and inter-ethnic relationships and the relationship with the State. Several studies done by various scholars in the past have tried to capture this macro and micro dimension of Nepalese society, ethnic group dynamics and their relations with state (Levine, 1987; Pfaff-Czarnecka, 1999; Gurung, 2003; Sharma, 2004; Hangen, 2005, 2007, 2009; Lawoti 2005; Gellner, Whelpton and Pfaff-Czarnecka 2008 [1997]). But, this paper tries to address a different question that is the instrumental aspect of ethnic mobilization where ethnic actors manipulate ethnicity thereby subsuming the diverse and rich network of ethnic group relations. Along with the success and excitement of the ethnic movement, ethnic entrepreneurship as a new phenomenon has emerged in the new democratic set up where selective leaders and activists are mobilizing ethnic sentiments.

\section{Data and Fieldwork}

This theme emerged out of an interaction among the Tharu people as a part of PhD fieldwork. Fieldwork was carried out among the Tharus in Nawalparasi district in selected villages ${ }^{2}$. Several open-ended interviews were conducted with local Tharu people, cultivators and farmers, school teachers, government employees, shopkeepers, local Tharu leaders, and migrant workers among others. Most of the interviews were conducted in individual settings while some interviews took place in group settings. Most of the interviews were recorded and transcribed verbatim and then translated into English. Since the theme of this paper is centered on a specific issue of ethnic mobilization and the role of ethnic entrepreneurs, selective qualitative data and narratives from the broader fieldwork have been used for the purpose of this paper.

\section{Conceptual Background}

An important question arises about how one should engage with the question of ethnic upsurge, conflict and confrontation taking place in Nepal in the recent decades. To what extent are these ethnic phenomena the creation of political or ethnic entrepreneurs? Although the contemporary manifestation of ethnicity and ethnic mobilization

2. Fieldwork was carried out in different cluster of settlements in three VDCs and one recently declared municipality. 


\section{4| Ishwari Bhattarai}

is one of the most complicated themes of examination, which can be studied through the perspectives of struggle for equality, identity, or instrumental mobilization and collective cultural recognition, all scholars engaging with this issue confront several contestations.

Sociologists have acknowledged that the term ethnicity or collective identity is a very vague and ambiguous term due to the slippery nature of ethnic relations (Malesevic, 2004, Yinger, 1985). In popular usage, 'ethnicity' has been used to describe human social interaction in relation to other groups (Banks, 1996) and it has an element of boundary distinction among the cultural groups based on the social organization of cultural differences (Barth, 1969). It has also been acknowledged that the term has a processual component and the term is still on the move (Glazer and Moynihan, 1975). There are several ways in which ethnicity or ethnic group is conceptualized and all of these conceptualizations have some shortcomings. ${ }^{3}$ Several attributes such as sense of common origin, history, culture, myths, memories, beliefs are important to constitute ethnic difference. These symbolic elements are selectively used to raise collective consciousness by the leaders for their advantage as well (Barth, 1995).

There are several conceptual differences among the scholars concerning the nature of social groups whether they are 'given', 'natural' or 'primordial' communities or whether they are socially constructed or whether it is also the creation of certain individuals, primarily leaders in order to mobilize or gain political support and the context in which these groups are placed (Brass, 1991). Primordialists argue that every individual carries some kind of cultural heritage based on ascriptive status such as the place of birth, real or presumed kinship relationship, religion, language and social or cultural practices that acquire 'natural' character in course of time or are 'taken for granted' by the individual which becomes basis for collective consciousness. However, the very idea of primordial sentiment, the process of construction of myths, memories, raising consciousness also appears to be constructed in one way or the other. Barth very rightly points out that depending on where we live,

3. Oommen (1997, pp. 36-37) summarizes at least five different senses in which ethnic group or ethnicity is conceptualized and the problems associated with the conceptualization. 


\section{5| Ishwari Bhattarai}

the social interaction with the societies that surround us, different stories are produced from the same kind of ethnic groups produce different kinds of results (Barth, 1995). In this context, it appears quite relevant to quote Barth at length who says that:

...the conflicts we see today are the work of mainly of middle echelon politicians who use the politics of cultural difference to further their ambitions for leadership. This is tempting to them because in ethnic identities they see a potential constituency, so to speak, waiting for them, and all they need to find is the key to set the process in motion. Leaders seek these constituencies and mobilize them by making select, contrastive cultural differences more salient, and preferably by linking them to grievances and injustices, whether in the past or escalating in the present. They mobilize such constituencies in dissatisfaction so that they can lead them to a promised satisfaction. They engage in confrontational politics where, in fact, the ethnic appeal of competing leaders or candidates is one that constantly aggravates conflict and contrast, because once you are on this trajectory, the more you can prove your own commitment by vociferous rhetoric, the more support and more authority you can claim. Candidates emphasize the total unreasonableness of others, and the constraints of the current situation to ensure the necessity that people join them so they can lead their followers to the promised land. The emergence of such a wave of ethnic mobilization also intensifies the processes of controlling, silencing and erasing experiences, thus progressively producing their own preconditions. Persons with a rich network of relationships and experiences that extend beyond the ethnic group are told that these things are banned, valueless, or worse, that they must no longer be allowed, that we must be strong and united to create the political force that is needed for our particular objectives. These objectives are formulated by the entrepreneurs as a package. People are not left free to choose and say "Yes, I want to activate my ethnic identity for this purpose but not for that purpose. I will support you on this policy, but not on that policy." Thus the collective process is one that dramatically restricts the freedom of persons to act and to choose. Blocks with prepackaged programs are 


\section{6| Ishwari Bhattarai}

created, and either/or choices imposed. People's diversity of life and choices in their own private lives are reduced, and their conceptions of who they are and what they might do are limited and cut back. (Barth, 1995, p. 7)

Observing the case of Tharu protest and mobilization escalating to violent conflict and confrontation, it would be pertinent to revisit the idea articulated by Barth (1995). The quotation above quite well summarizes the very nature of contemporary ethnic upsurge and collective sentiments based on ascription that can be instrumentally mobilized by ethnic or political entrepreneurs for their goals, can also be useful in understanding the case of Nepal. What makes the ethnic entrepreneurs to do so is another question. The very nature of contemporary developments of ethnicity and ethnic conflict in Nepal today can also be looked from the point of view of Barth. Scholars and academicians working on the issues of ethnic phenomena in Nepal confront several disagreement and contestations because of the nature of the picture projected in the permutations and combinations of the distinct social groups. These attributes are selectively used by the political entrepreneurs for politicization of ethnic sentiments. Pfaff-Czarnecka noted this problem more than a decade ago and puts it as:

The problem of describing ethnicity in Nepal begins as soon as the question concerning the numerical proportions of the groups involved is addressed. Nepal lacks accurate statistics, which prompts the various political entrepreneurs to indulge in ethnic arithmetic, claiming far larger proportions of the society than is actually the case. (Pfaff-Czarnecka, 1999, p. 46)

The shortcomings in the census data in categorization of different jaat-jati (social groups), is raised by many including the Tharu activists. A middle aged Tharu leader claimed that the Tharu population reported as 1.7 million by the recent state census is grossly underreported, and that their actual numbers in Nepal would be about 4 million. He also alleged that it was due to the faulty enumeration and categorization by the census where several sub-groups who write various surnames are clubbed under other social groups. This is exactly what Pfaff-Czarnecka highlights in the quotation above, and is one of the strategies used by the ethnic entrepreneurs to claim 


\section{7| Ishwari Bhattarai}

numerical dominance. This numerical dominance is important to articulate and capture ethnic sentiment and an easy tool to engage in politicization of cultural difference.

In the Nepalese context, about 125 caste and ethnic groups and 123 linguistic groups have been identified by the latest census (CBS 2011). While the categorization of castes and communities by the census is often viewed as problematic by the academicians as well as ethnic activists these groups are further clubbed into a broader set of ethnic categories forming limited set of ethnic contrasts. These broader categories are pahadi (hill people), madhesi (plains people), janjati (nationalities), dalits (ex-untouchables), aadivasi (indigenous), Hindus, non-Hindus, caste and non-caste groups, Bahun-Chhetri etc. If we explore the 'social morphology'(Durkheim, 1898) of the different groups, we find several substratum of population in different size and form with different contextual dynamics. Subsuming this with the larger phenomena of ethnic politics would lead to an ahistorical analysis.

\section{Tharu Mobilization and Protests}

When the Tharus were asked about the nature of conflict among social groups in their locality, or in their everyday social life, most of them, including male and female belonging to different age groups, repeatedly emphasized that the Tharus and Pahadis lived in 'harmony' since many decades. Again, this would be an oversimplification if we try to generalize and claim that there exist no conflict and contradiction at all, although there was no violent confrontation among the Tharus and Pahadi until recently.

The Tharu-Pahadi conflict took place at a time when the first elected constituent assembly (CA) had to promulgate a new federal constitution in Nepal by May 2012 there were several disagreements among the political parties on the nature of new polity, federalism, governance etc. As the final deadline of the elected constituent assembly was approaching different groups began organizing protests, rallies, often violent, raising their voices and demands to be ensured in the new constitution. Tharus also led one of the powerful mobilizations in Nawalparasi district in the same month which turned violent. The following is the sequence of events narrated by 


\section{8| Ishwari Bhattarai}

the Tharu informants, particularly the leaders and youths who had participated in the protests.

The Tharus of Nawalparasi called for a chakka jam (general transport strike) in May 2012. The date of protest coincided with another public mass meeting organized by the Bahun-Chhetri community, in Butwal, in the west of Nawlparasi. Taking into consideration the mass meeting organized by Bahun-Chhetri, the Tharu leaders were said to have taken a decision, in order to avoid potential conflict, the vehicles carrying Bahun-Chhetri people heading to the meeting would not be obstructed. This decision was said to have been made a couple of days before the scheduled strike called by the Tharus.

However, on the day of protest a different scenario emerged. Not all the participants in the protest were aware of the decision. Many Tharus gathered along the east west highway at different locations. The Tharu protestors were burning tyres on the road. One such location was along the highway in Kawaswoti where the Tharu National Museum is located. Since early morning many Tharus had gathered in front of the museum. At the same time a couple of buses carrying supporters of Bahun-Chhetri, heading to attend mass gathering in Butwal reached there. A confrontational situation emerged when the buses were stopped. The leaders were said to be divided into two camps whether to allow the movement of these buses. Few participants from the Tharu group pelted stones and smashed the windscreen of the bus. This triggered the clash and both parties landed up in a violent confrontation, where several individuals from both sides were injured. The Bahun-Chhetri gathering turned into an unruly mob and entered into the museum area where some huts were burnt, along with several bicycles and couple of motorcycles which were parked in the museum premise by the Tharu protestors. This complicated the situation further. After this incident many individuals belonging to the Tharus or the Pahadi who were sympathetic towards each other's programs and rights to protest got polarized to their own ethnic camps.

The very next day, the Tharu leaders called for a mass protest. The Tharu leadership had announced mandatory participation of at least one member from each household with sticks and batons 


\section{9| Ishwari Bhattarai}

or else absentee households ${ }^{4}$ would have to pay cash penalty. A huge number of Tharus gathered at the proposed area. They were emotionally charged with ethnic hatred against the Pahadis. The Pahadis too were instigated by some locals to confront the situation. The communities living in 'harmony' in the neighborhood, having a long history of everyday social interaction had turned violent, and the place of protest had turned into a battlefield. For a short period of time a sense of ethnic hatred developed among the Tharus and Pahadis.

A meeting was called by the district administration, to resolve the issue. All the local leaders, representatives of political parties, security officers were invited including the Tharu leaders. During the meeting it is said that the Tharus demanded for compensation for the loss of property in the Tharu museum and several other goods. Also they continued protest while the meeting was going on at the district administration office. Police and security forces had been deployed to control the crowd and disperse them, if necessary, since there was a possible scenario of a bloody confrontation. The leaders who were in the forefront of the protest got divided on whether the crowd should be allowed move out of the museum premise or not. A Tharu leader was also leading the mobilization said that they were aware that if the protestors were allowed to move out of the museum premise there would be a high chance of ethnic confrontation with the Bahun-Chhetri group. Some selected BahunChhetri leaders instigated their community members to confront the Tharus violently. Eventually the Tharu protestors clashed with the security forces where several Tharu protestors and security persons got injured. A young Tharu died due to bullet injuries by the police. One of the local Tharu leader was of the view that in case a member of the Pahadi group had killed the Tharu, it was more likely that it would lead to a riot like situation among the Tharus and Pahadis in their neighbourhoods. ${ }^{5}$

Three years after this incident, a second wave of ethnic mobilization and clashes were reported in the month of August 2015 in many

4. Several Tharu individuals who had participated in the protest reported that the non participant households had to pay penalty (Rs 100-500).

5. One of the Tharu leaders and also the participants of protest during the conversation on the context of the movement shared his experience. 


\section{0| Ishwari Bhattarai}

parts of Nepal. One of such mobilizations was carried out by the Tharus in the western Nepal. Deadly violence erupted where at least 8 security persons were killed by the Tharu protestors and several others injured. Local authorities had to declare curfew in order to bring the situation under control. A report published by the Human Rights Watch (HRW) in Nepal, also highlights this issue clearly. One of the paragraphs of the report states that:

Community leaders on both sides have used crude populist language which risks inflaming tensions. In Kailali district, communally-motivated attacks on property took place, most notably after protesters killed the eight police officers on August 24 [2015]...the political differences underlying these protests are largely polarized along communal lines. (https://www.hrw.org/report)

The report cited above argues that community leaders on both sides have used populist language which provoked people and eventually polarized them on communal lines. As Barth observes that in such instances, participants in the mobilization are not left free to judge 'right or wrong' and 'yes I want to activate my ethnic identity for this purpose but not for that purpose. I will support you on this policy, but not on that policy" (Barth, 1995, p. 7). As seen in the Tharu protests of 2012, some participants in the protests expressed that their non-participation would make them a target as it would seem like they were against the cause of their community. A young Tharu man who had participated in the movement in 2012 said:

I participated in the movement. It was organized by my community and I supported them. We had to go because at least one member was supposed to participate from each household. From some households more than 2-3 members participated. The absentee households had to pay fine of Rs 500 .

In another instance a 26 years old student, also participated in the movement said:

There are some individuals who want to take benefit out of such acts in both Bahun Chhetri communities as well as in Tharu community. They instigate ethnic conflict and take advantages. Sometimes political leaders too instigate confrontation because of their animosity and vested interest 


\section{1| Ishwari Bhattarai}

and they misguide people.

Similarly, another Tharu man aged 30, active in politics and a regular figure in literary and cultural circles explained about the ethnic confrontation:

I don't see any scenario of violent ethnic conflict here. But sometimes it happens. For instance, in the month of May 2012, I was participating in the protests. The most important and challenging issue here is that, there are some elements..., who want to instigate the ethnic conflict (jatia dwanda) and want to take advantage. Nowhere we have any kind of prolonged ethnic animosity among groups (Bhawanatmak rup ma jat jati ko ladai hune awastha katai chhaina). If that had been the case then in the course of the next few days, we would have been beaten by them [pahadi-BahunChhetri] or it would have been the other way around. But it did not happen. So, I don't see any potential ethnic conflict or violence in future, at least here.

In his opinion, there is no enduring ethnic animosity between the Tharus and Pahadi groups; instead there is a harmonious relationship and unity (bhawanatmak ekata chha). He further pointed out that 'someone' instigates violence among groups. In such a scenario, identifying 'right' or 'wrong' gets blurry. Similarly, the Tharus who participated in the movement themselves claimed that leaders, activists, or politicians play a role in inciting ethnic conflict and try to take advantage out of this exercise.

Some of the Tharus who are engaged in cultivation as well as other casual economic activities, said that they had disagreements with their leaders, activists who lead such movements but were found to be participating in such mobilization. As, it was a movement organized by their own Tharu fellows (Tharu jat ko andolan bhayeko le jana pareko, nagayera pani nahune). A few Tharu men and women claimed that they had participated in the movement reluctantly. Similarly, another illustration would also make it clear how different kind strategy is used in everyday cultural sphere.

In recent years Tharus have come up with their own priests for activities which were earlier performed by the Hindu-high caste 


\section{2| Ishwari Bhattarai}

Bahun (Brahman) priests in the Tharu households. As mentioned earlier, the Tharu leader narrated another interesting analogy. As he said, since there are 4 million Tharus, "let us assume that everyday at least 1000 Tharus die. For carrying out funeral activities, Brahmans are summoned, who take NRs 500 or more for his service. Everyday, NRs 500,000, which will total to NRs 15,000,000/month and NRs $180,000,000$ a year, will be transferred to Bahun." In order to avoid this 'money transfer' to Pahadi-Bahun and circulate it within Tharu community, the Tharus had to arrange priests from their own community, a new phenomenon that has developed in the last decade.

How many Tharus would summon a Tharu priest? In another conversation, a young Tharu man narrated an incident regarding his father's 84th birthday celebration (Chaurasi puja). His father, who had been taking help of a Bahun priest for every ritual activity until recently, was not open to the idea of summoning new Tharu priest. But, if his son called a Bahun priest then, he would have to pay cash penalty imposed by the local Tharu association. If he called for the Tharu priest his father would not be happy. So the chaurasi puja was yet to be performed. But, he also said that many Tharus in the locality have flouted the norms imposed by the association and continue with the tradition of taking help of Bahun priest. It appears that there is a careful interplay of traditional values and the new norms where the actors have to engage and negotiate with.

\section{Political Mobilization and Ethnic Entrepreneurs}

The Tharus are organized under the umbrella organization named the Tharu Kalyankarini Sabha, locally called (ThaKaSa). This organization was formed in $1949^{6}$ to promote ethnic consciousness and make demands for the support and development of Tharu communities (McDonaugh, 2008 [1997]). This organization as Gunaratne (2002) explains was led and dominated by the Tharu elites and educated landlords and the support base was limited to elites only, until very recently. In the last 10 years or so, it now

6. Tharu Kalyankari Sabha is considered the oldest ethnic organization founded in 1949 and it is also said that the organization antecedes back to 1922 (Gellner, 2007) 
has rapidly extended its presence to all Tharu village grass roots. It was found that that there were several village level committees of ThaKaSa in Nawalparasi as well.

Tharu leaders including those at grassroots level were found to be sharply divided in terms of political choices and were mostly found to be supporting the CPN (UML), and Nepali Congress while few other Tharus extended their support to other political parties. Until a decade ago, there were no ethnically based political parties among Tharu communities (McDonaugh, 2008 [1997], p. 279). A couple of such political parties among Tharus have been formed post 2006 such as Tharuhat Tarai Party Nepal (TTP-N), Federal Democratic National Front (Tharuhat), Tarai Madhesh Loktantrik Party, Madhesi Janaadhikar Forum, Madhesi Janadhikar Forum (Loktantrik), etc. among others. ${ }^{7}$ The appeal for these parties appears to be significantly less or in other words they are confined to their selective regions where they have some influence. The electoral result also suggests that even if the Tharu candidates have secured parliamentary seats in the national elections, those Tharu candidates were affiliated to the dominant political parties either CPN (UML) or Congress or UCPN (Maoist). Even if there were Tharu candidates contesting the elections representing their own ethnic political party, most of the Tharus were found to be voting for non-Tharu candidates belonging to dominant parties having nationwide presence. Although, the dynamics of election and voting pattern may not be that easy to generalize, and it is a matter of separate investigation, it is nonetheless important to raise a question, why there was less appeal among the Tharus to vote for their own candidates when they had a choice.

When a young, male Tharu teacher was asked if the local Tharu leaders are influential, his answer was negative. He said that since the beginning of the formation of the ThaKaSa the elites and landlords led the agenda of the Tharu movement. He said that they were the ones who used to be in contact with the rajya or the state, and rulers

7. Several other tarai parties are said to have been existing however their presence seems to be confined to certain regions of Nepal. Some other regional and ethnic parties are also existing. http://www.myrepublica.com/ portal/index.php?action=news_details\&news_id=86995 


\section{4| Ishwari Bhattarai}

by virtue of the position, power, resources and education at their disposal. He also said that they still dominate the superior position in the organization due to which the general Tharus do not have much appeal in them. According to him:

The Tharu activists in today's time are still the same old landlords who exercised their influence and dominance until the panchayat period but their influence has significantly weaned. It is a democracy now, there is freedom of expression. Earlier, they forcefully made everyone work under them in the form of attached labour (harua-charua). Now no-one obeys them and nobody wants to work under somebody else's domination. They still claim to raise the voice of Tharus, but people know them well that earlier they made us their slaves and lived a happy life until very recently. To add more into it, when the pahadia community migrated in this area, their dominance gradually weakened and it became easier for Tharus to liberate themselves. In fact, the Tharus achieved their freedom from their masters earlier than others. Despite gaining freedom from their masters long before, the Tharus still are unable to come into the mainstream society. It is because today too, the same old landlords and their generation is in the leadership position. The ordinary Tharus have not been able to trust them yet. As a result they have not been able to reach the top leadership positions in the national political scene yet.

He also further added that:

If the Tharu movement was led by Tharu leaders, who were from a non landlord family, like us, we would have trusted them. The old landlordism has demoralized the ordinary Tharus, who do not have courage and financial resources to take part in the politics (jamindari pratha le yesto manobal giradiyeko chha ani uni haru sanga sadhan ra arthik shrot pani chhaina). Only the landlords can afford to take part in politics, who have their own vested interests. For this matter landlords have resources and they can do. These are the reasons the Tharus have not been able to come to mainstream (rajya ko muldhar ma aauna nasaknu ko karan yo ho). In short, earlier the landlords used to raise voice of the Tharus, as they had financial and political power, and 


\section{5| Ishwari Bhattarai}

they raised voice of Tharus for their own benefit which the Tharus came to realize now (uniharu le tharu ko aawaz afno swartha ko lagi uthaye tyo kura ahile tharu le aayera bujhe). So the Tharus do not want them to win elections.

The above account further clarifies that the political allegiance is divided. It was unlikely that all of them vote for the same candidate. In response to the question of whom do Tharus vote during the elections, a young Tharu man responded, "anyone who claims to represent the voice of Tharus and who believe in the welfare of everyone would receive support from us." He added that even the Tharu candidates have since many years received support from Pahadia voters and won the general elections several times. Many Tharus also expressed that their voting pattern was sometimes influenced by the name of the political party, nature of the candidates, and win-ability factors among others. ${ }^{8}$ In this process, there is an element of shared cultural and social network that Tharus and nonTharus have developed over a period of time as said by the Tharu bhawanatmak ekata (emotional unity) that was acquired by the Tharus and non-Tharus living together closely. A number of interethnic marriages have taken place and there is a rich network of social relations among them. With this kind of ethnic polarization, often instigated by the selective entrepreneurs, the rich social fabric seems to be progressively ruptured. There appears a future risk that these mixed cultural heritages are going to be progressively destroyed through the ethnic entrepreneurial activity of selected key individuals.

\section{Concluding Observations}

This paper attempts to revisit the contemporary nature of ethnicity and ethnic conflict and the role of ethnic actors in actuating the conflict. Since ethnicity and mobilization of ethnic sentiment by ethnic entrepreneurs is a difficult and complicated topic, no generalizations can be made without sufficient elaboration. There

8. It was found that a Tharu candidate who had own in general elections several times had received support from Tharu as well as non-Tharu community. His influence is said to have reduced after he aligned with regional / ethnic party then he lost the recent elections and did not receive support from the Tharu people in the local area. 


\section{6| Ishwari Bhattarai}

is a risk of oversimplification when we try to deal with such a phenomenon which is unpredictable and rapidly changing and ambiguous in nature. So, to revisit the fundamental question which was attempted to address in this paper was how the contemporary nature of ethnic conflict is also in some way or the other, a tactical move carried out by ethnic entrepreneurs for their political gain. The illustrations presented above about the case of contemporary Tharu mobilization shows that there is an element of this kind.

In the last decade or so, the level of political consciousness has gone up to great extent among the Tharus. Everyone including Tharu men and women of all ages acknowledged this recent development. The rising sense of equality, dignity and citizenship has been one of the greatest achievements for them. But at the same time there was deep concern for growing sense of ethnic hatred among others which are particularly carried out by ethnic activists for political gain.

Why the ethnic entrepreneurs are tempted to act in this way? As noted by Barth the ethnic entrepreneurs see several benefits and mobilize the masses by harping on the contrastive cultural differences making them more salient, and engage in confrontational politics and constantly aggravate through different kinds of rhetoric. Barth further argues that, such a wave of ethnic mobilization intensifies the processes of "controlling, silencing and erasing experiences" and this in the end eventually destroys the rich network of social relationships that extend beyond the ethnic group. The leaders engage to create a strong political force for particular objectives (Barth, 1995, p. 7). It is an empirical matter that needs further investigation across several cases to come up with more comprehensive analysis. It will be more important and challenging task for researchers to engage with this aspect of ethnic mobilization, in wider contexts and settings across different cases among other 'minority ethnicity' as well as 'dominant ethnicity', i.e. Bahun-Chhetri too, for a robust understanding of the cases of ethnic entrepreneurs and political mobilization.

\section{References}

Barth, F. (1969). 'Introduction.' In F. Barth (ed.) Ethnic Groups and Boundaries: The Social Organization of Cultural Difference. Boston: Little Brown and Company. pp. 9-38. 


\section{7| Ishwari Bhattarai}

Barth, F. (1995). 'Ethnicity and the concept of culture' in Douglas R. Imig and Pamela Slavsky, (eds.), Non-violent Sanctions and Cultural Survivals Seminars, Cambridge, MA: Center for International Affairs, Harvard University

Banks, M. (1996). Ethnicity: Anthropological Constructions. Psychology Press.

Bennett, L. (1983). Dangerous Wives and Sacred Sisters: Social and Symbolic Roles of High-Caste Women in Nepal. Mandala Book Point: Kathmandu.

Brass, P. R. (1991). Ethnicity and nationalism: Theory and comparison. Sage Publications (CA).

Durkheim, E. (1898). 'Social Morphology' In Steven Lukes (eds.). Durkheim: The Rules of Sociological Method and Selected Texts on Sociology and its Method. 1982. Palgrave Macmillan. pp 184-85.

Glazer, N., \& Moynihan, D. P. (1975). Ethnicity: Theory and Experience. Harvard University Press. pp. 1-28.

Gellner, D. N. (2007). 'Caste, Ethnicity and Inequality in Nepal'. Economic and Political Weekly. May 9. pp. 1823-1828.

Government of Nepal, (2011). National Population and Housing Census 2011.

Guneratne, A. (2002). Many Tongues, One People: The Making of Tharu Identity in Nepal. Cornell University Press.

Gurung, H. (2003). Trident and Thunderbolt: Cultural Dynamics in Nepalese Politics. Kathmandu: Social Science Baha.

Hangen, S. (2005). 'Race and the Politics of Identity in Nepal'. Ethnology, pp. 49-64.

Hangen, S. (2007). Creating a 'New Nepal' an Ethnic Dimension. Washington: The East-West Centre Washington.

Hangen, Susan. 2009. The Rise of Ethnic Politics in Nepal: Democracy in the Margins. New Delhi: Routledge Publications.

Human Rights Watch. (2015). "Like We Are Not Nepali" Protest and Police Crackdown in the Terai Region of Nepal. Report available at https:/www.hrw.org/report/2015/10/16/weare-not-nepali/protest-and-police-crackdown-terai-regionnepal dated 16 Oct 2015.

Kaufmann, E. P. (2004). 'Introduction' in Kaufman E. P. (ed.) Rethinking ethnicity: Majority groups and dominant minorities. London: Routledge. pp. 1-12.

Lawoti, M. (2005). Towards Democratic Nepal: Inclusive Institutions 
for a Multicultural Society. New Delhi: Sage Publications. Levine, N. E. (1987). 'Caste, State and Ethnic Boundaries in Nepal'. The Journal of Asian Studies. Vol. 46, No 1. pp. 71-88 Malesevic, S. (2004). The Sociology of Ethnicity. London/Thousand Oaks/New Delhi: Sage Publications.

McDonaugh, C. (2008) [1997]. 'Losing Ground, Gaining Ground: Land and Change in a Tharu Community in Dang, West Nepal.' in D. N. Gellner, J. Pfaff-Czarnecka and J. Whelpton (eds.) Nationalism and Ethnicity in Nepal. Kathmandu: Vajra Books.

Oommen, T. K. (1997). Citizenship, Nationality and Ethnicity: Reconciling Competing Identities Cambridge: Polity Press. Pfaff-Czarnecka, J. (1999). 'Debating the State of Nation: Ethnicization of Politics in Nepal - A Position Paper.' In Joanna Pfaff-Czarnecka, Darini Rajasingham-Senanayake, Ashis Nandy, Edmund Terence Gomez. (eds.). Ethnic Futures: The State and Identity Politics in Asia. New Delhi/ Thousand Oaks/ London: Sage Publications. pp. 41-98.

Pfaff-Czarnecka, J. (2008) [1997]. 'Vestiges and Visions: Cultural Change in the Process of Nation-Building in Nepal'. In D.N. Gellner, J. Pfaff-Czarnecka and J. Whelpton (eds.) Nationalism and Ethnicity in Nepal. Kathmandu: Vajra Books. pp. 419-70.

Sharma, P. R. (2004). The State and Society in Nepal: Historical Foundations and Contemporary Trends. Kathmandu: Himal Books. pp. 203-62

Smith, A. D. (2004). 'Ethnic Cores and Dominant Ethnies' in Kaufmann, E. P. (ed.). Rethinking ethnicity: Majority groups and dominant minorities. London: Routledge. pp.15-26.

Whelpton, J., Gellner, D. N., Pfaff-Czarnecka, J. (2008). "New Nepal, New Ethnicities: Changes Since the Mid 1990s."

In D.N. Gellner, J. Pfaff-Czarnecka and J. Whelpton (eds.) Nationalism and Ethnicity in Nepal. Kathmandu: Vajra Books. pp. xvii-xlviii.

Yinger, J. Milton, (1985). 'Ethnicity'. Annual Review of Sociology.

Vol 11. pp. 151-80. 